\title{
Investigation of the psychological factors associated with fissured tongue
}

\author{
Investigação dos fatores psicológicos \\ associados à língua fissurada
}

\author{
Heron Fernando de Sousa GONZAGA ${ }^{\text {iD }}$ 0000-0001-9979-6472 \\ Lucinei Roberto de OLIVEIRA ${ }^{2}$ (D) 0000-0003-2637-6471 \\ Bruna Lavinas Sayed PICCIANI ${ }^{3}$ iD 0000-0001-7592-1785 \\ Maria Lúcia Jorge de Sousa GONZAGA ${ }^{1}$ iD 0000-0003-3714-3796 \\ Sílvia Angélica JORGE ${ }^{4}$ iD 0000-0001-9377-060X \\ Maria Augusta JORGE5 ${ }^{\text {iD }}$ 0000-0002-0088-2598 \\ Jane TOMIMORI ${ }^{6}$ iD 0000-0002-2407-6646
}

\section{ABSTRACT}

Objective: This study aimed to investigate the correlation between FT and anxiety. Methods: The sample consisted of 95 participants categorized into two groups: a) G-FT, 48 patients with FT and b) CG, 47 healthy participants. All patients were submitted to complete oral and dermatological examinations. The anxiety levels were measured using the State-Trait Anxiety Inventory (STAI). A p-value of $<0.05$ was considered significant. Results: Fourteen (30\%) patients reported awareness of having FT and 9 (64\%) were women. Symptoms like burning feeling were reported by $3(6 \%)$ only patients, all of then women. None of the control group patients presented these symptoms. In both groups, control and FT, the average scores of trait-anxiety were slightly higher than state-anxiety. There were no statistically significant differences between the FT and the control group related to the state-anxiety $(p=0.724)$ and the trait-anxiety $(p=0.680)$ scores. Study limitations: This study was limited by the number of subjects. Conclusion: Although moderate state-anxiety and trait-anxiety scores were determined, anxiety, as an environmental factor may not play a significant role in the development of FT. Considering FT as a multifactorial disease, probably a genetic component is necessary for expression.

Indexing terms: Anxiety. Dentistry. Fissured tongue.

\section{RESUMO}

Objetivo: Investigar a correlação entre língua fissurada e ansiedade. Métodos: A amostra consistiu em 95 participantes divididos em dois grupos: a) G-LF, 48 pacientes com língua fissurada e b) CG, 47 participantes saudáveis. Os pacientes foram submetidos aos exames

\footnotetext{
$\nabla \nabla v$

1 Universidade de Marília, Faculdade de Medicina, Dermatologia. Av. Rio Branco, 1132, Sala 122, 175002-000, Marília, SP, Brasil. Correspondência para / Correspondence to: HFS GONZAGA. E-mail: <herongonzaga@yahoo.com.br>.

2 Universidade Estadual de Campinas, Faculdade de Odontologia, Departamento de Patologia Oral. Piracicaba, SP, Brasil.

3 Universidade Federal Fluminense, Faculdade de Medicina, Departamento de Patologia. Niterói, RJ, Brasil.

${ }^{4}$ Universidade Estadual de Campinas, Hospital das Clínicas. Campinas, SP, Brasil.

${ }^{5}$ Centro de Educação Superior de Dracena - CESD. Dracena, SP, Brasil.

6 Universidade Federal de São Paulo, Escola Paulista de Medicina, Departamento de Dermatologia. São Paulo, SP, Brasil.

$\checkmark \nabla v$

How to cite this article

Gonzaga HFS, Oliveira LR, Picciani BLS, Gonzaga MLJS, Jorge MA, Tomimori J. Investigation of the psychological factors associated with fissured tongue. RGO, Rev Gaúch Odontol. 2019;67:e20190017. http://dx.doi.org/10.1590/1981-86372019000173559
} 
orais e dermatológicos. Os níveis de ansiedade foram medidos utilizando o Inventário de Ansiedade de Traçado do Estado (IDATE). Um valor de $p<0,05$ foi considerado significativo. Resultados: Quatorze (30\%) pacientes relataram ter consciência de língua fissurada e 9 (64\%) eram mulheres. Sintomas como sensação de queimação foram relatados por apenas 3 (6\%) pacientes. Nenhum dos pacientes do grupo controle apresentou esses sintomas. Nos dois grupos, controle e língua fissurada, os escores médios de ansiedade-tração foram ligeiramente superiores ao estado-ansiedade. Não houve diferenças estatisticamente significativas entre grupo língua fissurada e o grupo controle, relacionado ao estado-ansiedade $(p=0,724)$ e os achados traço-ansiedade $(p=0,680)$. Limitação: Este estudo é limitado devido o tamanho da amostra. Conclusão: Embora tenham sido determinados valores moderados de ansiedade de estado e traço-ansiedade, a ansiedade, como fator ambiental, pode não desempenhar um papel significativo no desenvolvimento de língua fissurada. Considerando língua fissurada como uma doença multifatorial, é necessário um componente genético para a expressão.

Termos de indexação: Língua fissurada. Odontologia. Ansiedade.

\section{INTRODUCTION}

Fissured tongue (FT) is a clinical condition manifested by numerous small furrows or slots on the tongue surface, usually spread from one medial central groove. However, its aspect may present variable patterns. The furrows commonly appear in the anterior two thirds of the tongue $[1,2]$. The fissures may be relatively superficial or deep. In this case accumulation of food debris, leading to unpleasant symptoms to the patient, like burning, inflammation and bad breath may be observed [3-5]. The etiology is not known, but several authors suggest a relationship between psoriasis, FT and benign migratory glossitis [6-8]. The presence of familial cases in psoriasis, benign migratory glossitis and FT suggest genetic basis and polygenic inheritance [4-9].

Emotional stress is reported to be a triggering factor in psoriasis and benign migratory glossitis. Both conditions have been associated with psychosomatic diseases [10-12]. However, reports studying emotional aspects in FT were not found in literature.

There are few studies assessing the etiology of FT as well as the clinical association of this condition with psoriasis and benign migratory glossitis, which has raised the hypothesis that emotional stress could be a triggering factor of FT.

This study aimed to investigate the correlation between FT and anxiety using the State-Trait Anxiety Inventory (STAI).

\section{METHODS}

The sample of this cross-sectional study consisted of 95 participants aged 18 years of age or older from the Dermatological Consultation of Beneficent Association at the University Hospital of Unimar, Marília, SP, Brazil. The study was approved by the local Research Ethics Committee.

Based on the stomatological examination, the participants were categorized in two groups: a) G-FT, 48 patients with FT and b) CG, 47 healthy participants. The subjects were excluded if they had skin diseases, autoimmune diseases, metabolic diseases, severe cardiovascular diseases, infections, use of immunosuppressive medications, allergies or possibility of a pregnancy at the time of evaluation. All patients were submitted to complete oral and dermatological examinations. The diagnostic criteria of FT were based on the presence of fissures. The anxiety levels were measured using the State-Trait Anxiety Inventory (STAI). The STAI contains two different scales to measure two distinct concepts of anxiety: state and trait. Each scale contains 20 items each one with 4 alternatives to answer. The scale of anxiety-trait requires the individuals to write how they generally feel, marking one of the alternatives. The scale of anxiety-state requires the individuals to answer how they feel at a given time, marking one of the alternatives [13]. All the statistical tests were performed using SPSS (Statistical Package for Social Sciences, v. 22.0). The statistical factorial and analysis of variance (ANOVA) test was performed for the obtained values of state/anxiety and trait/anxiety in both groups of patients. The level of statistical significance for all analyses was set at 5\% ( $p<$ 0.05). This study was approved by the Ethical Committee in Research at the Piracicaba Dentistry School/UNICAMP, protocol n 130/2001.

\section{RESULTS}

Among the 95 study participants, 48 (51\%) were men and 91 (96\%) were white. The patients were aged 18-83 years, with a mean age of 40 years in the G-FT and 30 years in the $C G$. 
Awareness of the presence of FT was reported by 14 patients (30\%), 9 of them women (64\%). The presence of symptoms, manifested as burning feeling, was reported by only 3 patients $(6 \%)$, all of them women. These symptoms consisted in burning, specially triggered by spice and hot foods and consumption of citric fruits. No patient in the control group presented these symptoms.

In both groups, control and FT, the average traitanxiety scores were slightly higher than state-anxiety. In these two groups, the average scores obtained for traitanxiety were statistically higher among female patients $(p=0.004)$. No statistically significant differences between the FT and the control group related to the state-anxiety $(p=0.724)$ and the trait-anxiety $(p=0.680)$ scores were found. Moderate state-anxiety and trait-anxiety scores were observed in each group, as shown in table 1.

\section{DISCUSSION}

The state of anxiety is conceived as a transitory emotional state or a condition of the human organism characterized by unpleasant feeling of tension and apprehension consciously noticed and an increase of the autonomous nervous system activity. This state may vary in time and intensity. Anxiety trait refers to relatively stable individual differences susceptible to anxiety, that is, the differences in the tendency to react to situations perceived as threatening with increase of intensity to the state of anxiety [13].

In 1966, Spielberger developed a self-evaluation scale of anxiety (State-Trait Anxiety Inventory - STAI) containing two distinct scales: Trait-Anxiety and StateAnxiety [13]. This instrument was translated into Portuguese language and adapted to the Brazilian reality by Biaggio et al. [14].

Several authors have applied the STAI to study the relationship of anxiety to the disease finding an association between benign migratory glossitis, arterial hypertension, graft versus host disease after bone marrow transplant, repercussions on fetal circulation during pregnancy, and allergic rhinitis [10,15-19].

Psoriasis and benign migratory glossitis have been associated with psychosomatic diseases [20]. From the established concepts about the subject at the time, several works were published linking emotional stress as one of the triggering causes of psoriasis and benign migratory glossitis [10,15,21]. Alikhani et al. [15] reported positive correlations between benign migratory glossitis, and physiological factors of anxiety, using STAI. However, despite the association between FT with psoriasis and benign migratory glossitis, no research has been found about emotional aspects associated with FT.

The etiology and pathogenesis of FT remain obscure and controversial $[1,5]$. FT has been associated to nutrition deficiencies, systemic diseases and syndromes $[1,2,22]$. Most FT epidemiological studies show a mean prevalence of 1 to $11 \%$, usually varying with age $[1,23]$.

Only $30 \%$ of the FT patients were aware of the oral alterations at the time of the consultation and $6 \%$ reported symptoms. These data show that the condition itself does not lead to discomfort to patients. A greater awareness of FT among women (19\%) suggested that they probably were better observers and they had a higher preoccupation about aesthetic aspects. Aboyans \& Ghaemmaghami [24] reported that more than $40 \%$ of the patients with FT present symptoms, differing from our outcomes of only $6 \%$ of symptomatic patients.

The patients of this study showed the same tendency as described on data among Brazilian and North American population, where women had a higher score in the STAI than men. The trait-anxiety scores found in the women's group were significantly higher comparing both groups. Wolfer \& Davis [25] pointed out that women

Table 1. Distribution of the mean and the standard deviation of state-anxiety and trait-anxiety scores in the FT and control groups by sex and in the entire sample.

\begin{tabular}{|c|c|c|c|c|}
\hline & State-anxiety & State-anxiety & Trait-anxiety & Trait-anxiety \\
\hline & FT & Control & FT & Control \\
\hline Male & $38.32 \pm 7.90$ & $38.53 \pm 8.77$ & $37.95 \pm 8.90$ & $38.03 \pm 8.48$ \\
\hline Female & $40.52 \pm 11.21$ & $42.13 \pm 10.19$ & $43.12 \pm 11.52$ & $44.95 \pm 9.78$ \\
\hline Total sample & $39.19 \pm 9.76$ & $40.18 \pm 9.52$ & $39.49 \pm 9.76$ & $41.20 \pm 9.65$ \\
\hline
\end{tabular}


usually express their emotions more easily than men. The higher trait-anxiety scores in women in both study and control groups observed in the present investigation may be explained by such ease of exteriorization of emotional state proposed by those authors.

No statistically significant differences between the FT group and the control group concerning to the state-anxiety and the trait-anxiety scores were found, but moderate scores of state-anxiety and trait-anxiety were found in each group. Environmental factors may have a role in the expression of the disease. Anxiety, as an environmental factor, seems not to have a predominant participation, but it could be one of the factors that trigger such condition [10]. The control group also presented moderate scores, but those individuals probably did not present a genetic predisposition.

Heredity has been proposed to have an important role in FT etiology $[4,26]$. The condition could have a polygenic nature or a dominant autosomal pattern with incomplete penetration and variable expressivity [4]. Some factors could trigger its development, but only in patients with inherited susceptibility [27]. The environmental influence that could become susceptive to FT is little known and speculative.

\section{CONCLUSION}

In conclusion, anxiety, as an environmental factor and regardless of the observed moderate state-anxiety and trait-anxiety scores, may not play a significant role in the development of FT. Considering FT as a multifactorial disease it is likely that a genetic component is necessary for its expression. The present study is the first of this type to investigate the anxiety in the FT.

\section{Collaborators}

HFS GONZAGA, substantial contributions to the conception or design of the work; the acquisition, and interpretation of data for the work; drafting the work and revising it critically for important intellectual content; final approval of the version to be published. LR OLIVEIRA, substantial contributions to the analysis and interpretation of data for the work; revising it critically for important intellectual content; final approval of the version to be published. BLS PICCIANI, revising it critically for important intellectual content; final approval of the version to be published. MLJS GONZAGA, revising it critically for important intellectual content; final approval of the version to be published. MA JORGE, contributions to the conception or design of the work; the acquisition, and interpretation of data for the work; revising it critically for important intellectual content; final approval of the version to be published. J TOMIMORI, revising it critically for important intellectual content; final approval of the version to be published.

\section{REFERENCES}

1. Feil ND, Filippi A. Frequency of fissured tongue (lingua plicata) as a function of age. Swiss Dent J. 2016;126(10):886-97.

2. Dafar A, Cevik-Aras H, Robledo-Sierra J, Mattsson U, Jontell M. Factors associated with geographic tongue and fissured tongue. Acta Odontol Scand. 2016;74(3):210-6. http://dx. doi.org/10.3109/00016357.2015.1087046

3. Binmadi NO, Jham BC, Meiller TF, Scheper MA. A case of a deeply fissured tongue. Oral Surg Oral Med Oral Pathol Oral Radiol Endod. 2010;109(5):659-63. http://dx.doi.org/ 10.1016/j.tripleo.2010.01.016

4. Eidelman E, Chosack A, Cohen T. Scrotal tongue and geographic tongue: polygenic and associated traits. Oral Surg Oral Med Oral Pathol. 1976;42(5):591-6.

5. Gonzaga HF, Marcos EV, Santana FC, Jorge MA, Tomimori J. HLA alleles in Brazilian patients with fissured tongue. J Eur Acad Dermatol Venereol. 2013;27(2):e166-70. http://dx.doi. org/10.1111/j.1468-3083.2012.04537.x

6. Gonzaga HF, Torres EA, Alchorne MM, Gerbase-Delima M Both psoriasis and benign migratory glossitis are associated with HLA-Cw6. Br J Dermatol. 1996;135(3):368-70. https:// doi.org/10.1046/j.1365-2133.1996.d01-1006.x

7. Picciani BL, Silva-Junior GO, Michalski-Santos B, Avelleira JC, Azulay DR, Pires FR, et al. Prevalence of oral manifestations in 203 patients with psoriasis. J Eur Acad Dermatol Venereol. 2011;25(12):1481-3. http://dx.doi.org/10.1111/j.1468-3083. 2010.03936.x

8. Zargari $O$. The prevalence and significance of fissured tongue and geographical tongue in psoriatic patients. Clin Exp Dermatol. 2006;31(2):192-5. https://doi.org/10.1111/j.1365-22 30.2005.02028.x

9. Ulmansky M, Michelle R, Azaz B. Oral psoriasis: report of six new cases. J Oral Pathol Med. 1995;24(1):42-5. https://doi. org/10.1111/j.1600-0714.1995.tb01128.x

10. Gonzaga HF, Chaves MD, Gonzaga LH, Picciani BL, Jorge MA, Dias EP, et al. Environmental factors in benign migratory glossitis and psoriasis: retrospective study of the association of emotional stress and alcohol and tobacco consumption with benign migratory glossitis and cutaneous psoriasis. J Eur Acad Dermatol Venereol. 2015;29(3):533-6. https://doi. org/10.1111/jdv.12616

11. Khalighinejad N, GorskyM. Psychological parametersassociated with geographic tongue: a clinical observation. Oral Surg Oral 
Med Oral Pathol Oral Radiol Endod. 2015;119(1):123. https:// doi.org/10.1016/j.0000.2014.10.005

12. Honarmand M, Farhad Mollashahi L, Shirzaiy M, Sehhatpour M. Geographic Tongue and Associated Risk Factors among Iranian Dental Patients. Iran J Public Health. 2013;42(2):215-9.

13. Spielberger CD. Anxiety and behavior. 1st ed. New York: Academic Press; 1966.

14. Biaggio AMB Natalício L, Spielberger CD. Desenvolvimento da forma experimental em português do Inventário de Ansiedade Traço-Estado (IDATE) de Spielberger. Arq Bras Psicol. 1977;19(3):31-44.

15. Alikhani M, Khalighinejad N, Ghalaiani P, Khaleghi MA, Askari E, Gorsky M. Immunologic and psychologic parameters associated with geographic tongue. Oral Surg Oral Med Oral Pathol Oral Radiol Endod. 2014;118(1):68-71. https://doi. org/10.1016/j.0000.2014.03.007

16. Lemche AV, Chaban OS, Lemche E. Trait anxiety but not state anxiety level associates with biomarkers for hypertension in the metabolic syndrome. Psychophysiology. 2016;53(6):914-20. https://doi.org/10.1111/psyp.12623

17. Gregurek R, Labar B, Mrsic M, Batinic D, Ladika I, Bogdanic $\mathrm{V}$, et al. Anxiety as a possible predictor of acute GVHD. Bone Marrow Transplant. 1996;18(3):585-9.

18. Sjostrom K, Valentin L, Thelin T, Marsal K. Maternal anxiety in late pregnancy and fetal hemodynamics. Eur J Obstet Gynecol Reprod Biol. 1997;74(2):149-55. https://doi.org/10.1016/ S0301-2115(97)00100-0

19. Addolorato G, Ancona C, Capristo E, Graziosetto R, Di Rienzo L, Maurizi M, et al. State and trait anxiety in women affected by allergic and vasomotor rhinitis. J Psychosom Res. 1999;46(3):283-9. https://doi.org/10.1016/S0022-3999(98)00 109-3
20. Lamb RC, Matcham F, Turner MA, Rayner L, Simpson A, Hotopf $M$, et al. Screening for anxiety and depression in people with psoriasis: a cross-sectional study in a tertiary referral setting. Br J Dermatol. 2017;176(4):1028-34. https:// doi.org/10.1111/bjd.14833

21. Gonzaga HFS, Aguiar FCA, Jorge MA, Jorge SA, Picciani $B L S$, Dias EP, et al. Evaluation of trait and state anxiety in patients with Benign Migratory Glossitis. Rev Bras Odontol. 2016;73(1):30-3.

22. Sudarshan R, Vijayabala G, Samata Y, Ravikiran A. Newer classification system for fissured tongue: an epidemiological approach. J Trop Med. 2015;2015:262079. http://dx.doi. org/10.1155/2015/262079

23. Darwazeh AM, Almelaih AA. Tongue lesions in a Jordanian population. Prevalence, symptoms, subject's knowledge and treatment provided. Med Oral Patol Oral Cir Bucal. 2011;16(6):e745-9. http://dx.doi.org/doi:10.4317/medoral. 17098

24. Aboyans V, Ghaemmaghami A. The incidence of fissured tongue among 4,009 Iranian dental outpatients. Oral Surg Oral Med Oral Pathol. 1973;36(1):34-8.

25. Wolfer JA, Davis CA. Assessment of surgical patients' preoperative emotional condition and postoperative welfare. Nurs Res. 1970;19(5):402-14.

26. Chosack A, Zadik D, Eidelman E. The prevalence of scrotal tongue and geographic tongue in 70,359 Israeli school children. Community Dent Oral Epidemiol. 1974;2(5):253-7. https://doi.org/10.1111/j.1600-0528.1974.tb01659.x-i1

27. Kullaa-Mikkonen A. Studies on lingua fissurata. Proc Finn Dent Soc. 1986;82(Suppl 4):1-48.

Received on: 15/2/2018 Final version resubmitted on: 25/4/2018 Approved on: 30/10/2018 